\title{
Sentencing Indigenous Riot Offenders in a Spatial FANTASY
}

\author{
Thalia Anthony*
}

\begin{abstract}
There is precedent in Australian criminal sentencing to consider Indigenous group membership as a mitigating factor, including for Indigenous riots against racist acts or deaths in custody. When mitigation has been invoked, it is based on the reduced moral culpability of the Indigenous offender. A number of higher courts, particularly in the 1980s and 1990s, pointed to the stress caused by racism that provoked the riot. However, recent sentencing remarks have tended to privilege aggravating circumstances, especially the seriousness of the riot and the harm or potential harm to the victims. This shift in sentencing considerations for rioters dovetails a reimagining of the Indigenous offenders and their communities as lacking reason or legitimacy in the contest for space. This article analyses key sentencing remarks and media reports for New South Wales and Queensland Indigenous riot cases over the past 30 years by drawing on Stanley Cohen's concept of 'moral panics' and Ghassan Hage's notion of spatial racism to demonstrate how the construction of riots as an out-of-control response reflects a deeper national anxiety over 'white' space.
\end{abstract}

Whether the offence is riotous or righteous, criminal sentencing provides unique opportunities for individualised justice. While normative sentencing principles, such as deterrence, retribution, rehabilitation and community protection, frame judicial discretion, such discretion is exercised with reference to the offender's background and circumstances. Sentencing principles are enshrined in legislation across Australia, including section 3A of the Crimes (Sentencing Procedure) Act 1999 (NSW) and section 9(1) of the Penalties and Sentencing Act 1992 (Qld). At the same time, the High Court of Australia has remarked that courts have discretion to 'take account of all relevant factors'.' Judicial discretion ensures 'individualised justice' by requiring 'that all of the wide variations of circumstances of the offence and the offender are taken into account'. ${ }^{2}$ Individualised justice is a long-

Senior Lecturer, Faculty of Law, University of Technology Sydney. The author would like to thank Amanda Porter for her thoughtful feedback on earlier versions and her creation of the term 'riotous or righteous'. The author would also like to acknowledge the helpful suggestions of David Lewis, Roshan De Silva and the anonymous reviewers.

$1 \quad$ Wong $v$ The Queen; Leung $v$ The Queen (2001) 207 CLR 584 at 611 (emphasis in original).

$2 \quad R v$ Whyte (2002) 134 A Crim R 53 at 77 (Spigelman CJ). 
standing principle in Australian sentencing ${ }^{3}$ and has withstood the trend to fixed penalties in the United States. ${ }^{4}$ Tata likens sentencing to craftwork, where the craftworker aims for consistency in applying rules, but nonetheless leaves a personal signature to signify that the work was treated as uniquely individual. ${ }^{5}$ Part of the discretionary patchwork includes the offender's background, cultural identity and group membership. ${ }^{6}$

Mitigating and aggravating factors are set out in legislation in Queensland and New South Wales. In Queensland, section 9(2)(g) of the Penalties and Sentences Act 1992 provides that the court 'must have regard to the presence of any aggravating or mitigating factor concerning the offender'. It outlines a range of specific considerations including, since an amendment in 2000, 'any submissions made by a representative of the community justice group in the [Indigenous] offender's community' under section 9(2)(p). ${ }^{7}$ In New South Wales, section 21A of the Crimes Sentencing Procedure Act 1999 lists the mitigating and aggravating factors for the court to consider, as well as providing the sentencing court with discretion to consider other relevant objective or subjective factors. Indigenous background does not represent a mitigating or aggravating factor per se. The common law establishes that Indigenous group membership is one of the many 'material facts' that courts are 'bound to take into account' when imposing sentences. ${ }^{8}$ There is a body of case law on specific facts that may be relevant to Indigenous offenders, including the socioeconomic disadvantage of their community ( $R \quad v$ Fernando $),{ }^{9}$ the existence of Indigenous laws and cultural practices $(R v \text { Shannon })^{10}$ and the dispensation of punishment on the offender by his/her Indigenous community $(R v$ Minor). ${ }^{11}$

\section{Gleeson (1995).}

$4 \quad$ Edney and Bagaric (2007), p 16. However, mandatory prison sentences have crept in to Western Australian legislation (in relation to burglary: Criminal Code Compilation Act (WA), s 401(4)) and Northern Territory legislation (in relation to certain violent offenders and sexual offenders: Sentencing Act (NT), ss78BA-BB).

Tata (2007), pp 426, 437.

Neal v The Queen (1982) 149 CLR 305 at 326.

Such submissions were put in Lex Wotton's case: The Queen v Lex Patrick Wotton [2008] Townsville District Court (Unreported, 7 November, TOWN3/2008) at 13. Although there is little authority on section $9(2)(\mathrm{p})$, it has been relied on to accept community justice submissions on the defendant's role in ensuring her children's attendance at school where Aboriginal school attendance rates are low in the community ( $R v$ Chong; ex parte A-G (Qld) [2008] QCA 22 at [9]-[11]). The provision is also the legislative basis for the establishment of the Murri Courts in Queensland: Hennessy (2006).

Neal v The Queen (1982) 149 CLR 305 at 326 (Brennan J).

$R v$ Fernando (1992) 76 A Crim R 58.

$R v$ Shannon (1991) 56 A Crim R 56.

$R v$ Minor (1992) 105 FLR 180. See generally on Indigenous sentencing factors, Anthony (2010). 
Criminologists suggest that judicial recognition of individual offender circumstances, particularly socioeconomic background, contributes to fairer outcomes in sentencing. ${ }^{12}$ It recognises the culpability of the offender and their relative lack of choice over their actions. Tonry justifies sentencing mitigation for the poor by reasoning that their actions are less culpable than those who are not so afflicted. ${ }^{13}$ Hudson goes so far as to argue that accommodation of an offender's poorer economic conditions should be based on 'principled criteria' rather than 'individual representations for particularly sympathetic cases'. ${ }^{14}$ This call for the application of principled criteria is supported by Tata's observation that judicial officers 'become wearied by narratives about deprivation and social disadvantage' in presentence reports. ${ }^{15}$ Hudson asserts that, due to 'widening social inequalities' that limit offenders' choices, 'justice demands that society acknowledge responsibility [for the economic hardship] by assisting the offender' in sentencing. ${ }^{16}$ She states that 'the extent to which [offenders] are to be blamed - and therefore punished - should reflect these differences and inequalities'. ${ }^{17}$

By failing to consider individual factors, criminologists argue that offenders receive sentences disproportionate to their culpability. ${ }^{18}$ Ashworth criticises sentencing calculations based on the seriousness of the harm and the assumption of offender autonomy, given that 'strong social disadvantages may be at the root of much offending'. ${ }^{19}$ In relation to Indigenous offenders, Gray and colleagues argue that special consideration should be given to 'Aboriginality' in sentencing because otherwise 'racism [emerges] by way of adherence to values, systems, procedures and outcomes that exclude others of a different culture and background' ${ }^{20}$ Sentencing should involve reintegrative strategies for disadvantaged offenders, according to McCoy. She remarks that 'fashioning sentencing structures' to take account of 'social inequality, true psychological pathologies of some individuals, and culpability of members of a common moral community' would integrate 'members of the underclass' into the 'common community'. ${ }^{21}$

This criminological literature on sentencing is valuable for analysing Indigenous offenders who have been sentenced for riot offences. This is not

12 Hudson (1999), p 583. However, there is also a coterie of criminologists who regard incarceration as the only rational response to criminals, such as Bennett et al (1996).

13 Tonry (1995), p 125.

Hudson (1999), p 583.

Tata (2010), p 246.

Hudson (1999), pp 589-90.

Hudson (1999), p 585.

Ashworth (2002), p 1079; Hudson (1999), p 564.

Ashworth (2005), p 86.

Gray et al (2008), p 119.

McCoy (1997), pp 611-12. 
only because they come from low socioeconomic backgrounds, but also because they have limited means of redress when the provoking racist act is inflicted by the government or police who are meant to provide protection from such acts. To varying degrees, the sentencing remarks discussed below recognise this limited choice. However, a principled body of case law addressing the criminological concern that sentencing should account for offenders' narrowed choices and society's contribution to social inequalities and prejudices is yet to develop.

\section{Offsetting Indigeneity in Riot Cases}

This article analyses a corpus of sentencing remarks for Indigenous offenders who were convicted of assault or riot for violently protesting against police or government officials for their racist acts or involvement in a death in custody or police chase. The protesters in these cases were also expressing broader grievances about systemic and institutional discrimination against Indigenous people. ${ }^{22}$ The riots represented not individual attacks but rather a contest over space and its appropriation by white control. The sentencing remarks were delivered for offenders who protested through assaulting (spitting on) a government officer on Yarrabah Reserve (North Queensland) in 1981,23 rioting against the death in police custody of an Indigenous man at Brewarrina (Western New South Wales) in $1987 ;^{24}$ rioting in 2004 against the death on a police chase in Redfern, Sydney; ${ }^{25}$ and rioting (including with destruction to property) against the death in custody on Palm Island, Queensland in 2004. ${ }^{26}$

These sentencing remarks illustrate how courts variously imagine the Indigenous background of the offender and their community. In the earlier sentencing remarks in relation to Yarrabah $^{27}$ and Brewarrina, ${ }^{28}$ the appellate courts demonstrated an appreciation of the personal stress the offenders were under during the offences due to discrimination, paternalism and overpolicing. Their circumstances reduced the offenders' culpability, and in turn the seriousness of their offence and the sentence. These appellate courts treated the seriousness of the offence as encapsulating culpability. It would later be divorced from individual culpability and linked exclusively to harm or potential harm in justifying harsher sentences for the Redfern and Palm

\footnotetext{
See: Funnell (2005); Cunneen (2007).

Neal $v$ The Queen (1982) 149 CLR 305.

$R v$ Murray, $R v$ Bates [1992] NSWCCA (Unreported, 6 April, CCA 60322 of 1991, CCA 60343 of 1991); $R v$ Boney [1991] NSWCCA (Unreported, 22 July, No 60342/91).

$25 \quad R v$ Cargill [2005] NSWDC (Unreported, 6 January, Audio recording of proceedings).

$26 \quad R v$ Poynter, Norman \& Parker; ex parte A-G (Qld) [2006] QCA 517; The Queen $v$ Lex Patrick Wotton [2008] Townsville District Court (Unreported, 7 November, TOWN3/2008).

$27 \quad$ Neal $v$ The Queen (1982) 149 CLR 305 at 325;

$28 \quad R v$ Boney [1991] NSWCCA (Unreported, 22 July, No 60342/91) at 6.
} 
Island rioters. ${ }^{29}$ Criminological theory has highlighted that a 'central dimension' of the seriousness of the offence is the offender's culpability, and this should be capable of reducing a sentence..$^{30}$

The Redfern and Palm Island riot cases resonate with the broader penal shift from a primary concern with the offender's culpability to the victim's harm (or, more likely, potential harm).$^{31}$ The law and order turn has been characterised by a penal focus on vindicating the victim by providing punishment proportionate to the harm to the victim..$^{32}$ The seriousness of the offence, both in sentencing and popular perceptions, therefore is measured increasingly against the impact on the victim rather than the circumstances of the offender. In The Culture of Control, Garland remarks that the victim is routinely invoked 'in support of measures of punitive segregation'.$^{33}$ Pratt reminds us that the harm inflicted on victims is treated as harm inflicted on the rest of society to justify 'much greater penal severity'. ${ }^{34}$ The new punitive focus on the dangerous offender and vulnerable victim is based on 'the quite distinct logic of risk calculation' ${ }^{35}$ It is distinct from earlier inquiries into the circumstances of the offender, including their environment, group membership and motivations. ${ }^{36}$ The emphasis is on the ideal victim, ${ }^{37}$ who "consists of a category of individuals who - when hit by crime - most readily are given the complete and legitimate status of being a victim'. ${ }^{38}$ They are characterised by weakness (especially in relation to the offender), performing a respectable role and having a virtuous moral character. ${ }^{39}$ Sentencing courts' narration of police as such victims mutes the wrongdoing of the police in deaths in custody and attempts to create a fantasy of racial neutrality in the management of space..$^{40}$

New South Wales District Court quoted in Levett and Kennedy (2004), p 6; $R$ v Poynter, Norman \& Parker; ex parte A-G (Qld) [2006] QCA 517 at [15], [21], [28]; The Queen v Lex Patrick Wotton [2008] Townsville District Court (Unreported, 7 November, TOWN3/2008) at 4.

Von Hirsch (2004), p361. See also Ashworth (2005); Easton and Piper (2005), p 60.

See Garland (2001); Simon (2007). at [5], [29], [33]. 


\section{Moral Panics, Riots and Contested Space}

Courts in riot cases that have downplayed factors relating to culpability have also imagined the Indigenous community as lacking rational capacity. This echoes a moral panic about the threat of Indigenous people to the social order. In the Palm Island case, the Queensland Court of Criminal Appeal regarded the Indigenous offenders as being out of control and not reasonably responding to an injustice. ${ }^{41}$ The sentencing remarks concluded that the offenders had the same set of choices as other people ${ }^{42}$ rather than, in the words of Hudson, having 'increased pressures towards crime'. ${ }^{43}$ In the sentencing of the Redfern and Palm Island rioters, their marginalised position in relations with police and their ongoing contest over space was not averred either by the courts or in the mainstream media. ${ }^{44}$ Commenting on the reporting of the Redfern riot, Gargett points to the media's erasure of the narrative of 'desperation and frustration' within the Indigenous community. ${ }^{45}$ Cunneen argues in relation to the Palm Island riot that the media ignored questions of why the act occurred and produced a story of 'blind, lawless purposelessness'. ${ }^{46}$ Instead, the media highlighted Indigenous people's dysfunctionality and pathos to create a story of 'passive victims' who were 'without clear intention or rational motivations for engaging in particular activities'. ${ }^{47}$ The rioters were denied a role in creating their own political space through their resistance. ${ }^{48}$

The mainstream media's characterisation of Indigenous riots can be described in Cohen's terms as creating 'moral panic'. The participants were presented as irrational deviants and outsiders who were placing Australian society 'under imminent threat' ${ }^{49}$ Cohen writes that a moral panic arises when a:

condition, episode, person or group of persons emerges to become defined as a threat to societal values and interests; its nature is presented in a stylized and stereotypical fashion by the mass media; the moral barricades are manned by editors, bishops, politicians and other right-thinking people. ${ }^{50}$

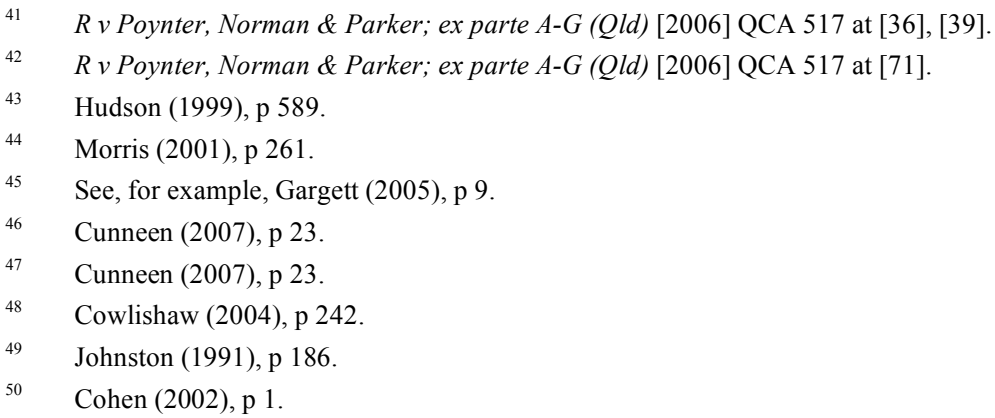


The characterisation of 'riots' as 'chaotic spontaneity', according to Scraton, ${ }^{51}$ undermines their status as 'reasoned responses' to discriminatory policing. Silver explains that defining popular protests as criminal acts pursued by disorganised 'rabble' ensures their illegitimacy and reinforces the legitimate response of the police..$^{52}$ During the trials and sentencing of Indigenous rioters examined in this article, the media sought to undercut the rationality of the riot and vindicate the police victims.

Historical and anthropological analyses of riots suggest that they are 'articulate protests against genuine grievances'.$^{53}$ Rationality, rather than irrationality, according to Fogelson, is among a riot's 'most crucial features'. ${ }^{54}$ In his classic essay on nineteenth century English riots, Silver refers to their socioeconomic-political nature, ${ }^{55}$ whereas Cowlishaw describes Indigenous riots as also having cultural, spatial and historical meanings. ${ }^{56}$ For Silver, riots served an important social function: to communicate 'the desires of the population' to elites. ${ }^{57}$ Historians and anthropologists note that riots are organic, with varying levels of organisation, ${ }^{58}$ restraint $^{59}$ and impulsiveness. ${ }^{60}$ Individuals may not perceive themselves as being involved in an organised act. ${ }^{61}$ Some are responding to the direct provocation of and enticement by the police. ${ }^{62}$ Police violence in response to a crowd can lead rioters to adopt 'an exaggerated form of destructive mayhem and defiance' ${ }^{63}$ Alternatively, some Indigenous rioters have attempted to assist the police by preventing their harm. This is noted by Cowlishaw in relation to the 1997 Bourke riot, ${ }^{64}$ and was alleged in Lex Wotton's sentencing submissions on his involvement in the Palm Island riot. ${ }^{65}$

The portrayal of riots in the white media and political circles assumes a 'homogenous [Indigenous] citizenry', with invalid claims to space. ${ }^{66}$ It fails to recognise that Indigenous identity is not only linked to race, but also to

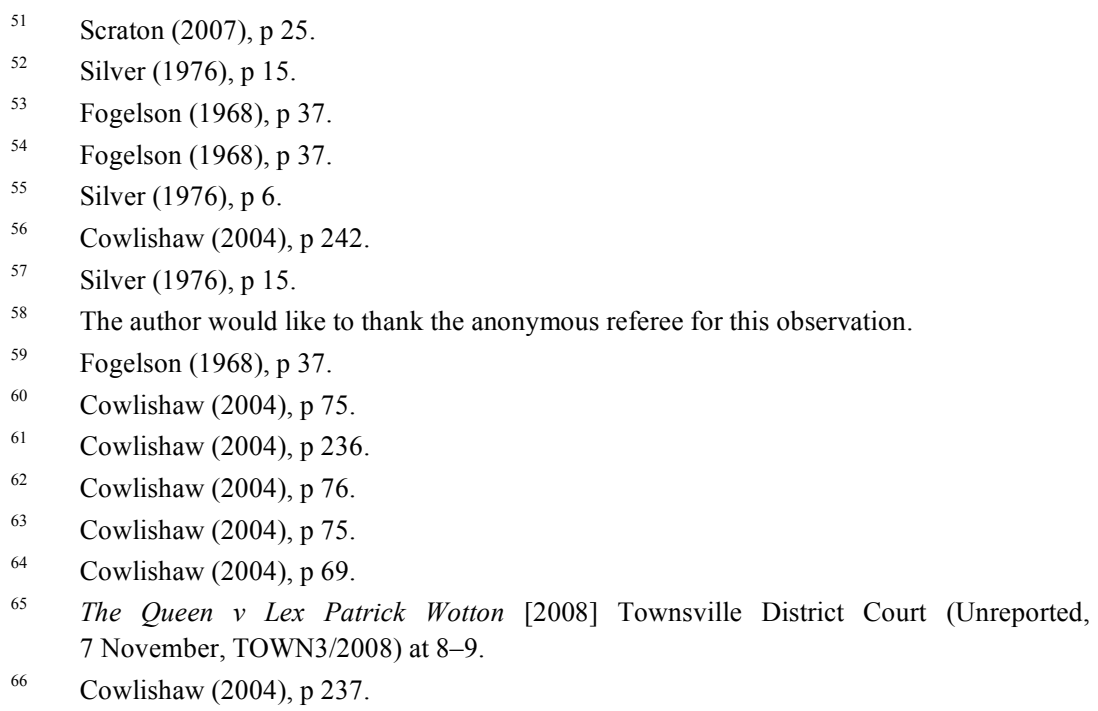


territory. ${ }^{67}$ This is a feature of Australian nationalist ideology, which asserts that claims to territory can only be made by European Australians. ${ }^{68}$ For Hage, the "whiteness ${ }^{69}$ of space has critical significance for settler societies that are based on the creation of an 'imagined community' and 'internal orientalism'..$^{70}$ Nationalism is based on 'spatial management', involving the preservation of an 'imagined privileged relation' over 'race' and 'national space'. ${ }^{71}$ Ang also notes that 'white racism in the Australian context has peculiarities which have to do with the spatial dimensions of this settler colonial project'. ${ }^{72}$ The distance of the 'mother country' produced 'a particularly antipodean sense of place, a spatial consciousness of self and of the world moulded by the experience of occupying this vast, distant land, which was perceived as nearly empty'. ${ }^{73}$ She explains that the

totalising nature of British annexation and control paved the way ... for the creation of 'one Australia' ... imagined in terms of a transplanted British homogeneity. In other words, what was produced here was the collapsing into one of physical and human geography, which had a powerful imaginative effect on the white settlers. It provided the fledgling settler society with a singular sense of spatial identity. ${ }^{74}$

The riot brings to the fore this contest over territory. As a collective act, the riot seeks to 'force political matters into view', ${ }^{75}$ and to construct a political challenge. ${ }^{76}$ In the words of Cowlishaw, the Indigenous riot is 'ordered around a conversation with whitefellas'. ${ }^{77}$ It creates 'a productive space where racialized bodies carry powerful messages' and 'police stand accused of interfering in others' domestic spaces' ${ }^{78}$ Cowlishaw notes that 'violent actions are needed to shatter the complacency and moral superiority

Frankenberg argues that race is constructed as much through place as through more orthodox indicators such as physical appearance: Frankenberg (1993), pp 43-70.

Hage (1998), p 32.

'Whiteness' is a cultural historical construct: Hage (1998), pp 58-59. It involves 'both a European monopolisation of "civilised humanity" and a parallel monopolisation of Whiteness as its marker': Hage (2003), pp 49-50.

Hage (1998), p 17, emphasis in original. This draws on Benedict Anderson's 'imagined community', which is determined without reference to the actual members of the community, and Edward Said's Orientalism, in which the Other is reduced to a passive object of government.

Hage (1998), p 38.

Ang (1999), p 191.

Ang (1999), p 191.

Ang (1999), p 192.

Cowlishaw (2004), pp 244-45.

Cowlishaw (2004), p 75.

Cowlishaw (2004), p 195.

Cowlishaw (2004), p 245. 
[over Indigenous people] that accompany and naturalize the state power' ${ }^{79}$ The destruction of property is an attack on the economic control of towns by whites, and sends a message about the 'clumsy limit of police power'. ${ }^{80}$ However, the rioters' claims to space do not receive the same national attention as the deniers of their space. Although the riot can be regarded as a spatial contest, it is the 'spatial managers', including the courts and media, who are entitled to publicise their opinions about those who do not belong and should be excluded from the space. ${ }^{81}$ By contrast, the "spatially managed' have opinions expressed about them. ${ }^{82}$ This constructs the managed not only as inferior but 'as an object of spatial exclusion' ${ }^{83}$ Media and court representations of Indigenous rioters as uncontained rabble are a legacy of the colonial mentality that allowed Indigenous people to be segregated and their places to be claimed and named by whites. ${ }^{84}$

Spatial encounters defined the organisation of 'settler' space in Redfern and Palm Island. These two sites exemplify divergent approaches to colonisation in Australia. Redfern is a place that Aboriginal people have struggled to hold on to, and it remains 'embattled' ${ }^{85}$ Aboriginal people at Redfern were dispossessed of their land in the early nineteenth century despite resistance led by Pemulwuy. From the late nineteenth century, Aboriginal people returned to Redfern to take up employment on the railway and reclaim a pocket of their land. Over the next century, the Aboriginal population grew to 12,000 by 1965 and Redfern became a home for the Aboriginal rights movement. ${ }^{86}$ Anderson notes that 'Redfern became a sphere of [I]ndigenous protest, an heroic site of resistance to European culture and colonialist control' ${ }^{87}$ In 1973, the Aboriginal Housing Company bought housing in an area of Redfern ${ }^{88}$ that would come to be known as 'The Block' ${ }^{89}$ This purchase was regarded as 'part of the process of selfdetermination and reconciliation'. ${ }^{90}$ It has since been 'owned and occupied' by the Aboriginal community, ${ }^{91}$ and 'remains the symbolic heart of (post)colonial political struggle'. ${ }^{2}$

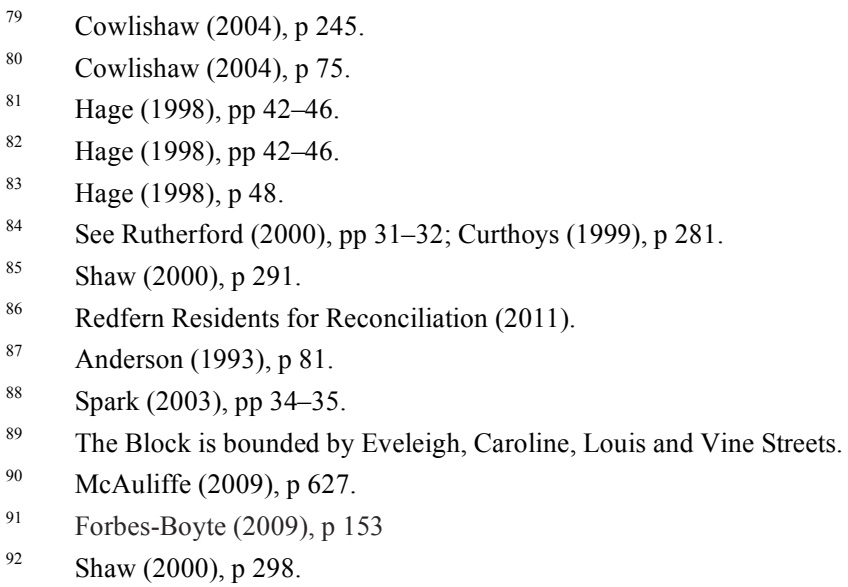


Since its beginnings, The Block has been challenged by high-level policing and popular criticisms that the area 'is imploding in a sea of drugs, crime and cultural inferiority" ${ }^{93}$ and is an example of 'failed (urban) Aboriginal self-determination'. ${ }^{4}$ Narratives of the out-of-'placeness' of urban Aboriginal people help to justify white claims to The Block. ${ }^{95}$ Aboriginal struggles and achievements at Redfern are constructed as inferior to the progress of 'colonial capitalism' ${ }^{96}$ Spark reminds us that:

As tempting as it may be to imagine spaces apart from their corporeal realities, these are illusory: there are no places of self-determination that exist outside places produced through colonialism and assimilation. ${ }^{97}$

In the late 1990s, the gentrification of inner-city Sydney emerged as 'the latest phase of capitalism's re-colonisation of inner city residential space'. ${ }^{98}$ The Redfern Riot, which brought the spatial contest over Redfern into sharp relief, sparked calls from the New South Wales opposition leader for 'bulldozers' to 'flatten the area known as the Block'. ${ }^{9}$

The genesis of Palm Island as a colonial space took a different track from Redfern. Settler space was organised along penal lines from 1918, and Indigenous people from the mainland were often detained there for violating Queensland's Aboriginal Protection Act. ${ }^{100}$ The purpose of the penal settlement, as stated by Queensland's Chief Protector of Aboriginals in the early twentieth century, was to confine and punish Indigenous 'troublesome cases' and assure colonial expansion on the mainland. ${ }^{101}$ Punishment was harsh, including incarceration in the watch-house, and could be inflicted on an Indigenous person for novel reasons such as laughing. ${ }^{102}$ The spatial boundaries were fiercely enforced by whites on the island, and Indigenous people were unable to visit white zones. ${ }^{103}$ They also could not walk into shops but had to queue for rations, and had to 'salute any white person they passed' ${ }^{104}$ Despite Palm Island being inhabited by its own Indigenous and non-detainee population, ${ }^{105}$ Indigenous residents could not escape the

\footnotetext{
Shaw (2000), p 291.

Shaw (2000), p 291.

Shaw (2007).

Anderson (1999), p 215.

Spark (2003), p 36.

Shaw (2000), p 296.

Anon (2004e).

Watson (2010).

Watson (2010), p 18.

Watson (2010), p 104.

Watson (2010), p 110.

Watson (2010), p 82.

Watson (2010), p 19.
} 
criminal label and the ensuing policing and white control. ${ }^{106}$ Nonetheless, Indigenous people on the island continue to resist white policy, echoing the opposition to the Aboriginal Protection Act that brought many to the island. Such resistance materialised in a 1957 strike against withholding Indigenous wages and the violent rule by white authorities, and through protesting in the white zones, as well as in the establishment of the Palm Island Aboriginal Community Council. In 2004, the Palm Island riot exposed the ongoing tensions with white authority. Similar spatial struggles are apparent on other reserves, such as Yarrabah, discussed in relation to the Neal case below.

The terms of white spatial management are not delivered through a singular message. They ebb and flow between romanticisation and condemnation of Indigenous people. To be solely aggressive would undermine the imagined social harmony created within national borders. Therefore, colonisers match moments of lawlessness with lawfulness 'through the elaboration of a new fantasised form of social harmony', according to Rutherford. ${ }^{107}$ In criminal sentencing, both goodwill and reprimand are variously imposed on the Indigenous offender to create an image of a social order in control. In riot cases, sentencing courts have embraced the riot as a measure of human progress that is compatible with white society's aspirations. Alternatively, they have romanticised the paternalism and segregation policy of white society to contrast with the uncontrolled rioter and deviant Indigenous subject. ${ }^{108}$ This antinomy in sentencing is symptomatic of 'Australian cultural formations' in which 'power to do good' through social engineering has 'deprived Aboriginal Australians at every turn'. ${ }^{109}$ The Frankfurt School suggests that the state acts out a paternal role in which its caring nature becomes disciplinarian when the relationship between the nation and the subject deteriorates. ${ }^{110}$ For Hage, this epitomises the tendencies of Australian nationalism between 'evil white' and 'good white' nationalism. ${ }^{111}$

\section{Early Judicial Portrayals of Indigenous Rioters: Entitled to be Agitators}

Neal v The Queen (1982) is one of the few High Court cases to consider the relevance of Indigenous group membership to sentencing considerations. The court found that it could reduce the sentence because Indigenous background was relevant to the moral culpability of the offender and the

\footnotetext{
106 Wilson (1982).

107 Rutherford (2000), p 57.

108 Cairns Magistrates Court, quoted in Neal v The Queen (1982) 149 CLR 305 at 325; Bathurst District Court's sentencing remarks for Brewarrina rioters Bates and Murray, quoted in Lewis (1991a), p 6.

109 Rutherford (2000), p 27.

110 See Fromm (1963); Adorno et al (1950).

111 Hage (1998), p 79; see also Hage (2003), p 39.
} 
seriousness of the offence. ${ }^{112}$ Neal $v$ The Queen involved an Indigenous offender who committed a violent offence after being provoked by racism. The circumstances of the offence were a confrontation on the Yarrabah Aboriginal Reserve between Mr Collins, a non-Indigenous officer of the Department of Aboriginal Affairs and store manager on the reserve, and the accused, Percy Conrad Neal, the elected chairman of the Yarrabah Community Council on the reserve. Neal had campaigned against the paternalistic treatment of Indigenous people on the reserve by white authorities, and sought to institute Aboriginal self-management, which was a political issue for Indigenous communities across Australia. The deep-seated grievances over the paternalist environment found expression when Collins sold rotten meat to the Indigenous people on the reserve. With twelve other Indigenous people, Neal sought out Collins at his home. While the others waited on the street, Neal had an argument about reserve management. $\mathrm{He}$ swore at Collins, telling him that he was racist and that he and all other whites should get off Yarrabah reserve. He then spat in Collins' face. For this, Neal was convicted of unlawful entry and assault. ${ }^{113}$

At first instance, a Cairns magistrate sentenced Neal to imprisonment for two months. The magistrate criticised the political statement behind the act of resistance: 'Your actions in taking unto yourself the task of removing all whites from Yarrabah cannot be condoned from any angle. ${ }^{\text {'14 }}$ He blamed Neal for the racial tensions between black and white society: 'Violence is something in recent times which has crept into Aboriginal communities: I blame your type for this growing hatred of black against white.' ${ }^{115}$ Neal was regarded as upsetting 'the harmonious running of these communities'. ${ }^{116}$ This reflects, as Hage suggests, a fantasy of the invisible yet racialised European hegemony. ${ }^{117}$ Hage points to Goffman's idea that 'illusions and impressions' about space are 'necessary for the construction of the self' ${ }^{118}$ It is the judicial 'presentation of the self' as tolerant that is superimposed on white Australia's treatment of Others. ${ }^{119}$ Equally, the image of harmony is threatened when the Other fails to acquiesce to the hegemony.

The Queensland Court of Criminal Appeal, upon hearing Neal's appeal, increased the sentence to six months' imprisonment on the basis that the two-month sentence was manifestly inadequate for such an offence that involved 'a mob'. ${ }^{120}$ Neal successfully appealed to the High Court, which reinstated the magistrate's two-month sentence. Two of the four judges,

\footnotetext{
$112 \quad$ Neal v The Queen (1982) 149 CLR 305 at 325.

$113 \quad$ Neal v The Queen (1982) 149 CLR 305 at 311, 321.

114 Quoted in Neal v The Queen (1982) 149 CLR 305 at 325.

115 Quoted in Neal v The Queen (1982) 149 CLR 305 at 325.

116 Quoted in Neal v The Queen (1982) 149 CLR 305 at 325.

117 Hage (1998).

118 Hage (1998), p 155.

119 Hage (1998), p 155.

120 Quoted in Nealv The Queen (1982) 149 CLR 305 at 313.
} 
Gibbs CJ and Wilson J, allowed Neal's appeal on the technical basis that the Court of Criminal Appeal was acting ultra vires by extending the sentence. ${ }^{121}$ All judges accepted that racial tensions on reserves were legitimate sentencing considerations. Wilson $\mathrm{J}$ held that the magistrate's sentence appropriately took into account the 'frustration and emotional concern engendered in [Neal] by the manner in which the reserves were administered and his endeavour to obtain self-management'. ${ }^{122}$ Like Wilson J, Brennan J personalised the act by focusing on the 'emotional stress' created by the 'paternalistic system' of the reserve, which affected Neal. ${ }^{123}$ Nonetheless, Brennan J appreciated that it did not arise from 'any ill-feeling between Messrs Collins and Neal personally', but was a 'dramatic and emotional confrontation' produced 'by a deeply-felt objection to departmental control of the reserve'. ${ }^{24}$ The objection was a 'material factor' that went to 'the reason why Mr Neal engaged in that conduct' and reduced the 'gravity for the offence'. ${ }^{125}$ In an oft-quoted statement, Brennan $\mathrm{J}$ pointed to the importance of Indigenous circumstances in sentencing considerations:

In imposing sentences courts are bound to take into account, in accordance with those principles, all material facts including those facts which exist only by reason of the offender's membership of an ethnic or other group. So much is essential to the even administration of criminal justice. ${ }^{126}$

The treatment of Aboriginal people on the reserve and Neal's grievances were relevant to moral culpability and a reduced sentence. Brennan J accepted that Neal was 'entitled lawfully to advocate political or administrative changes without penalty'. ${ }^{127}$ Murphy $\mathrm{J}$ went further in tracing the 'Aboriginal sense of grievance' that 'developed over the two hundred years of white settlement in Australia', with its 'arrogant superiority' and 'considerable brutality'. ${ }^{128}$ This resonates with Cowlishaw's observations that Indigenous riots emerge from a 'colonial rage' ${ }^{129}$ Murphy $\mathrm{J}$ recognised that 'Aborigines have a right to participate in and direct their own policies' and protest against the 'reserve conditions and race relations', which are to be treated as special mitigating factors in a sentence. ${ }^{130} \mathrm{He}$ cited US experience where 'persons frustrated by powerlessness through the exercise of racist

\footnotetext{
121

Neal v The Queen (1982) 149 CLR 305 at 307-8, 320.

Neal v The Queen (1982) 149 CLR 305 at 320.

Neal v The Queen (1982) 149 CLR 305 at 325.

Neal $v$ The Queen (1982) 149 CLR 305 at 324.

Neal v The Queen (1982) 149 CLR 305 at 323-24.

Neal $v$ The Queen (1982) 149 CLR 305 at 326.

Neal v The Queen (1982) 149 CLR 305 at 325.

Neal v The Queen (1982) 149 CLR 305 at 317.

Cowlishaw (2004), p 195.

Neal v The Queen (1982) 149 CLR 305 at 318.
} 
policies and practices ... sometimes express [grievances] in the only way possible - by protest or violence'. ${ }^{131}$ Murphy $\mathrm{J}$ further stated that Neal as an agitator was 'in good company' and 'agitators are so absolutely necessary' for 'human progress' and 'advance towards civilisation'. ${ }^{132}$ Brennan and Murphy JJ's comments remind us that the space of the reserve is not fixed, but a 'shared space' that 'emerges relationally'. ${ }^{133}$ Paul Carter reflects on the formation of public space not as governed by the law but as a 'mobile and self-constituting' set of exchanges between Indigenous and non-Indigenous systems. ${ }^{134}$

Ultimately, Murphy $\mathrm{J}$ treated sentencing mitigation as a vehicle for reconciliation between Indigenous and non-Indigenous Australians. He gave meaning to Hudson's theory that sentencing should involve 'society acknowledg[ing] responsibility' for the circumstances that led to the offending. ${ }^{135}$ Murphy $\mathbf{J}$ was in favour of imposing a non-custodial sentence, as a prison sentence would 'not improve race relations but will tend to embitter them'. ${ }^{136}$ For Murphy J, the inferior status of Indigenous people vis$\grave{a}$-vis the white victim in a position of authority was a special mitigating consideration:

Taking into account the racial relations aspect of this case, the fact that $\mathrm{Mr}$ Neal was placed in a position of inferiority to the whites managing the Reserve should have been a special mitigating factor in determining sentence. ${ }^{137}$

All judges of the High Court enunciated that the stress of racism on the offender reduced the seriousness of the offence. ${ }^{138}$ However, with the exception of Murphy $J$, the court regarded the space of Yarrabah Reserve as a white legal space, with tolerance for difference in this space something the white system bestowed on Indigenous people. As Hage notes, white notions of cultural diversity hinge on whites possessing the terms of its existence,

\footnotetext{
$131 \quad$ Neal $v$ The Queen (1982) 149 CLR 305 at 318.

$132 \quad$ Neal $v$ The Queen (1982) 149 CLR 305 at 318.

133 Carter (2007), p 440.

134 Carter (2007), p 430.

135 Hudson (1999), p 590.

$136 \quad$ Neal $v$ The Queen (1982) 149 CLR 305 at 318.

$137 \quad$ Neal v The Queen (1982) 149 CLR 305 at 318.
}

138 The position in Neal that sentencing courts are bound to account for material facts of ethnic group membership has been applied to Indigenous offenders who receive traditional punishment (Jadurin $v R$ (1982) 44 ALR 424 at 429; $R v$ Minor (1992) 105 FLR 180 at 191; $R v$ Miyatatawuy (1996) 87 A Crim R 574 at 579); those who come from low-socioeconomic backgrounds (Rogers and Murray $v$ The Queen (1989) 44 A Crim R 301 at 307); those who belong to communities inflicted with alcohol abuse (Fernando $v R$ (1992) 76 A Crim R 58 at 62; $R v$ Churchill [2000] WASCA 230); and those who were members of the Stolen Generations ( $R$ v Fuller-Cust (2002) 6 VR 496 at [60]). 
rather than cultural diversity undercutting whiteness. ${ }^{139}$ Similar social fantasies of tolerance to difference are created in the sentencing of the Brewarrina rioters.

\section{Sentencing Brewarrina 'Rioters' in the Aftermath of Boney's Death in Custody}

The catalyst for the Brewarrina riot of 1987 was the death in custody of a local Indigenous man and the perceived failure of the justice system to bring the responsible police to account. Brewarrina is a small town of about 1000 people in North-Western New South Wales, with a large and impoverished Aboriginal population. It is a town not unlike Bourke, which Cowlishaw characterises as beset by ongoing spatial contests between Indigenous and non-Indigenous residents. ${ }^{140}$ The backdrop to the riot was anger at the forthcoming celebrations of Australia's Bicentenary at Brewarrina, the overpolicing of Indigenous people and a growing movement against a spate of Aboriginal deaths in custody across Australia. A number of rioters would stand trial and their sentencing submissions would highlight the death in custody as the precursor to the riot. In 1991, the New South Wales Court of Criminal Appeal reviewed the sentences of a number of the rioters, and regarded the death in custody and high-level policing as mitigating factors. ${ }^{141}$

\section{The Death in Custody and Moral Panics}

Leading up to the riot, policing had intensified in Brewarrina in anticipation of protests against Australia's Bicentennial celebrations. ${ }^{142}$ During this time, Lloyd James Boney, a 28-year-old Indigenous man, died in police custody. Boney was found hanging by a football sock in a police cell one and a half hours after he was arrested for breaching bail conditions. ${ }^{143}$ The Indigenous community was suspicious of the police involvement in the death, and demanded a proper inquiry and justice to be served against the police. The community took the view that it was physically impossible for Boney to kill

\footnotetext{
139 Hage (1998), p 140.

140 Cowlishaw (2004).

${ }^{141} \quad R v$ Murray, $R$ v Bates [1992] NSWCCA (Unreported, 6 April, CCA 60322 of 1991, CCA 60343 of 1991) at 9; $R$ v Boney [1991] NSWCCA (Unreported, 22 July, No 60342/91) at $1-2$.
}

142 The Tactical Response Group was mobilised to Brewarrina due to police fears about an Indigenous insurrection as a result of Australia's Bicentennial celebrations of colonisation: RCIADIC (1991). There was also a 'law and order' campaign among the New South Wales government and opposition in the lead-up to the 1988 election that 'positioned nonAborigines as victims of "Aboriginal criminality" and called for more policing in places like Brewarrina: Morris (2001), p 248. However, these developments merely confirmed to the Indigenous community at Brewarrina the police mistreatment and subsequent grievances that had 'festered over many years': Cunneen and Robb (1987), p 263, quoting a Brewarrina protester.

143 Hope (1991), p 2. 
himself by hanging in his heavily intoxicated state. ${ }^{144}$ Also, as a "happy-golucky guy', Boney was seen as lacking the disposition for suicide. ${ }^{145}$ At the same time, Boney had expressed fear that the police would kill him. ${ }^{146}$ There was growing publicity across Australia about both Aboriginal deaths in custody and police mistreatment of Aboriginal people. The Committee to Defend Black Rights had been monitoring deaths in custody in 1987 and found an average of one death every eleven days, which had led to calls for a Royal Commission into Aboriginal Deaths in Custody. ${ }^{147}$ Boney was the sixteenth Aboriginal death and the final straw that would lead to the federal government forming a Royal Commission. ${ }^{148}$ The Commission later found that there was a 'widespread view' among Indigenous people that Boney's death was part of a pattern of Indigenous deaths in custody. ${ }^{149}$

The Indigenous community at Brewarrina was outraged by the police removing Boney's body to Bourke before notifying his family of his death and also at what they saw as police lies about attempting to organise bail for Boney, according to the Royal Commission. ${ }^{150}$ These events 'aroused suspicion of a cover-up of a killing'. ${ }^{151}$ There was an overnight internal investigation into the death, involving only one interview conducted by the Internal Security Unit with a police officer. The findings were that Boney had committed suicide with 'no suggestion at all of foul play in any sense' on the part of the police. ${ }^{152}$ Consequently, there was a strong view in the community that justice would not be served through lawful channels.

In the week following Boney's death, a series of protests took place outside the police station. When riot-clad police with shields and batons turned up to Boney's wake, and in doing so flouted an agreement between the Western Aboriginal Legal Service and the police, the 'Brewarrina riot' materialised. ${ }^{153}$ In response, about 20 mourners armed themselves with iron bars and fence posts and shouted, 'Black people have been killed by white people for more than 200 years' ${ }^{154}$ The riot lasted for about 40 minutes, during which the rioters broke windows at the local hotel. ${ }^{155}$ Two police officers were taken to hospital, with one sustaining a broken leg. ${ }^{156}$ There

\footnotetext{
144 Wootten (1991), pp 2, 97-98; Williams and Cordell (1987b), p 1; Williams and Cordell (1987a), p 8 .

145 Wootten (1991); Williams and Cordell (1987b), p 1.

146 Williams (1988), p 7.

147 Williams and Cordell (1987b), p 1.

148 Tatz (1996), p 11.

149 Wootten (1991), p 1.

150 Wootten (1991), pp 17, 55-62.

151 Wotton (1991), p 17.

152 Wotton (1991), p 124.

153 Pitty (1994), p 10.

154 Lewis (1991c), p 3.

155 Duboudin (1987).

156 Hewett (1987), p 1.
} 
was one report of an Indigenous man in the riot who was taken to hospital. Most injuries sustained by Indigenous people, including by those sentenced for the riot, went unreported. ${ }^{157}$

Seventeen Indigenous people - labelled the 'Brewarrina 17' - were arrested for riot and riot-related offences. ${ }^{158}$ The most serious charges and convictions for riotous assembly and assaulting police were laid against 'ringleaders' Arthur Murray (an Aboriginal elder who was a campaigner for the Royal Commission into Aboriginal Deaths in Custody and whose son had died in police custody in 1981), Soney Bates (Lloyd Boney's brother-inlaw) and Glen Boney (Lloyd Boney's cousin). ${ }^{159}$ The ensuing moral panic in the mainstream media highlighted the violence of the riot and the role of its protagonists. The media focused on the uncontrollable and intoxicated state of the rioters, ${ }^{160}$ which was televised during the trials. ${ }^{161}$ Headlines read 'Blood on the Street: the Night a Town Exploded' 162 and 'Police Hurt in Clash with Aborigines' ${ }^{163}$ AAP reported that 'a mob of aborigines attacked police in an outback town' ${ }^{164}$ Journalists described how beer bottles were stacked in the park as weapons and ammunition. ${ }^{165}$

However, some media reports were balanced with a portrayal of the death in custody and the police provocation as underlying the protest. This nuanced narrative would later manifest in the sentencing remarks for Murray, Bates and Boney. Reports identified the death in custody and police racism as precursors to the riot. ${ }^{166}$ The Sydney Morning Herald described the riot as an act of resistance to the death in custody, poor living conditions and 200 years of Aboriginal abuse ${ }^{167}$ The article stated that the violence was that "practised by oppressed groups at "the end of their tether" to beg "the dominant group to take notice of their inhuman plight' ${ }^{168}$ A journalist questioned official reports of the numbers of Indigenous rioters, claiming it was closer to 30 than the 150 that the police alleged. ${ }^{169}$ In its front-page story, the Sydney Morning Herald quoted James Boney, Lloyd's brother,

\footnotetext{
157 Fife-Yeomans (1988), p 8; Pitty (1994), p 9.

158 The inspector who investigated Lloyd Boney's death in custody also investigated the rioters, which the Indigenous community viewed as biased: Wootten (1991), p 125. $R v$ Murray, $R v$ Bates [1992] NSWCCA (Unreported, 6 April, CCA 60322 of 1991, CCA 60343 of 1991) at 13 .

160 This view was also publicly expressed by Mark Olson, the coroner appointed to inquire into the death of Lloyd Boney, cited in Carter (1987), p 18.

161 Morris (2001), p 261.

162 Hewett (1987a), p 1.

163 Anon (1987)

164 Anon (1987).

165 Lewis (1991a), p 6.

166 Anon (1987a), p 16; Hewett (1987a), p 1.

167 Anon (1987a), p 16.

168 Anon (1987a), p 16.

169 Anon (1987a), p 16.
} 
who alleged that the police had been harassing his family and that Aboriginal people were looked upon as 'less than human'. ${ }^{170}$

\section{Court of Criminal Appeal's Latitude for Context of Death in Custody}

The Bathurst District Court's first instance sentence for rioters Bates and Murray emphasised the violent, unpredictable and unstable nature of the Indigenous community at Brewarrina. ${ }^{171}$ The court, whose remarks were directly quoted in the media, did not portray the riot as a reasoned response to the death in custody, despite the contemporaneous handing down of the Royal Commission's report on Boney's death, recommending disciplinary action against the police officers. ${ }^{172}$ Indeed, the court directed the jury to ignore the death in custody as a causal factor and the commission's findings. ${ }^{173}$ The court depicted Murray and Bates as responsible for disturbing community harmony by promoting hatred of police. The court reflected on the harmonious Aboriginal-white relations in the 'old days' of the 1950s and 1960s, when whites controlled Indigenous lives and 'whites and blacks' lived 'happily together' ${ }^{174}$ The worsening of race relations was evidenced by Indigenous people attacking police in what 'could only be described as a completely unprovoked and violent riot'. ${ }^{175}$ In handing down eighteen-month prison sentences for riotous assembly, the court concluded that the rioters had been affected by alcohol in carrying out their "half-hour of madness'. ${ }^{176}$ This reasoning reveals the District Court's capacity for fantasy creation about a harmony that is based on the invisibility of white racial dominance alongside a narrative that makes Indigenous deviance visible. ${ }^{177}$

The appeal to the New South Wales Court of Criminal Appeal against the convictions and sentences of Bates and Murray, and the sentence of Glen Boney, focused on District Court Nash J's alleged biased interventions and his failure to consider the death in custody as a mitigating sentencing consideration. ${ }^{178}$ The Court of Criminal Appeal found that Nash J gave an 'unhelpful review of the evidence' that 'weighed unfairly against the accused' and gave the 'impression that World War III was taking place in Brewarrina that night'. ${ }^{179}$ It was critical of the District Court's idealising of

\footnotetext{
170 Hewett (1987a), p 1.

171 Morris (2001), p 246.

172 Hope (1991), p 2.

173 Lewis (1991a), p 6.

174 Quoted in Lewis (1991b), p 3.

175 Lewis (1991b) p 3 (emphasis added), quoting Nash J.

176 Lewis (1991b) p 3.

177 Hage (1998), pp 78-79.

$178 \quad R v$ Murray, $R v$ Bates [1992] NSWCCA (Unreported, 6 April, CCA 60322 of 1991, CCA 60343 of 1991) at 22. 
the 'virtuous' past of racial discrimination and its blaming of Indigenous people for the problems relating to the tense relations with non-Indigenous people. For the appellate court, the problems confronting the Indigenous community could be explained with reference to its harsh treatment by nonIndigenous society, including by the police. It put the death in custody at the forefront of assessing the offenders' conduct. ${ }^{180}$ Ultimately, the convictions were quashed due to the bias of the District Court and the insufficient numbers to constitute a riot. ${ }^{181}$ Nonetheless, the court accepted that the death in custody should have been a relevant factor:

It would have been quite unrealistic for the jury to have considered the specific blows alleged to have been inflicted by each of the accused upon which the riot charge was based without knowledge of the initial reason for which the crowd had gathered (following the funeral of the Aboriginal man who died in police custody). ${ }^{182}$

The other defendant, Glen Boney, appealed against his six-month prison sentence on the basis that the Bathurst District Court gave him a disproportionate sentence compared with the other rioters, and failed to account for the death in custody in mitigation. The Court of Criminal Appeal described the death in custody as a mitigating factor for Boney's offence of assaulting police. It noted the 'close emotional relationship between the applicant and the deceased [Lloyd Boney] in that they had been raised, effectively, as brothers' ${ }^{183}$ Accordingly, the death had a significant personal impact on the defendant, which should have been considered in the sentence. Grove J of the Court of Appeal recognised that 'a number of people had acquired a notion that the death of Lloyd Boney had, in some fashion, been facilitated or even brought about by acts of police officers' ${ }^{184}$ Grove J held that many of the 'adherents to the[se] beliefs' were part of the 'large crowd of mourners' at the funeral. ${ }^{185}$ Ultimately, Boney was released, having served 75 days, because the 'subjective consideration of the applicant's close relationship to the person believed to have died unnecessarily must have borne some weight'. ${ }^{186}$

The contrast between the District Court's reasoning and that of the appeal court reveals how new fantasies of social harmony vacillate, as Rutherford suggests, between moments of lawlessness and lawfulness in the

\footnotetext{
$180 \quad R v$ Murray, $R$ v Bates [1992] NSWCCA (Unreported, 6 April, CCA 60322 of 1991, CCA 60343 of 1991) at 2 .

$181 \quad R v$ Murray, $R v$ Bates [1992] NSWCCA (Unreported, 6 April, CCA 60322 of 1991, CCA 60343 of 1991) at 6 .

$182 \quad R v$ Murray, $R$ v Bates [1992] NSWCCA (Unreported, 6 April, CCA 60322 of 1991, CCA 60343 of 1991) at 9 .

$183 \quad R v$ Boney [1991] NSWCCA (Unreported, 22 July, No 60342/91) at 1.

$184 \quad R v$ Boney [1991] NSWCCA (Unreported, 22 July, No 60342/91) at 1-2.

$185 R v$ Boney [1991] NSWCCA (Unreported, 22 July, No 60342/91) at 2.

$186 \quad R v$ Boney [1991] NSWCCA (Unreported, 22 July, No 60342/91) at 6.
} 
law's narratives about Indigenous offenders. ${ }^{187}$ Rutherford explains this schizophrenic national psyche through the lens of Jacques Lacan's psychoanalysis. ${ }^{188}$ The contrary forces of transgressing the limit of the pleasure principle and enforcing it through the law 'facilitates an analysis of Australian morality and of its counterpart: an aggression to the internal and external Other'. ${ }^{189}$ In its sentencing considerations, the Court of Criminal Appeal acknowledged the fraught relations between the police and Indigenous communities that placed considerable stress on offenders as relevant to reducing the culpability of the offender and the seriousness of the offence. The court regarded the Indigenous community as having legitimate grievances in relation to the death in custody. It displayed sympathy for the circumstances of the community and the offenders, while denouncing the District Court's view that Indigenous people should be blamed for their hardship. For the Court of Criminal Appeal, the moral cause of the Brewarrina rioters due to their personal loss and political grievances was a means to lessen their culpability.

The remainder of this article addresses how courts sentencing recent 'riot' offenders have tended to focus on the seriousness of the riot offence rather than culpability, and have reimagined the Indigenous community grievance leading up to the riot - namely, the death in custody - as an illegitimate ground for mitigation. It reveals the foreboding aspect of the Australian psyche where the fantasy of a universal white culture denies the validity of specific Indigenous concerns.

\section{Punitive Approaches to Sentencing Redfern 'Rioters' After the Death of TJ Hickey}

\section{Redfern Riot and Media Portrayals}

At least since the late 1960s, the Indigenous community at Redfern has been subject to over-policing and police aggression, and has responded with resistance. ${ }^{190}$ The 'Redfern riot' that took place on the night of 15 February 2004 was not an isolated event, but rather a culmination of tense Indigenous-police relations and white claims to The Block. ${ }^{191}$ The high-level policing of Redfern has perpetuated 'notions of risk and ever-present danger' ${ }^{192}$ and 'enabled a widespread expectation and acceptance that The Block must go'. ${ }^{193}$ The Block is seen as belonging to whiteness and existing

\footnotetext{
187 Rutherford (2000), p 57.

188 Rutherford (2000), p 27.

189 Rutherford (2000), p 27 (emphasis added).
}

190 The over-policing of Redfern, including police raids throughout the 1990s, sparked public protests and widespread policy debates: Cunneen (2001), pp 99-100; see also Tickner (1982); Cunneen (1990).

191 Funnell (2005).

192 Shaw (2009), p 432.

193 Shaw (2000), pp 298-99. 
in white space. ${ }^{194}$ While Indigenous people's resistance to white claims and policing often manifests in 'quiet persistence' to hold on to their space, ${ }^{195}$ it can also erupt in contestation, as occurred after Thomas 'TJ' Hickey's death. Hickey was a seventeen-year-old Indigenous boy who lived at Redfern and was impaled on a fence as a result of a police chase that was observed by Indigenous community members. The community widely believes that the police were responsible for the death. ${ }^{196}$ Within a few hours of TJ's death, posters were put around Redfern stating 'WANTED Child Murderers' and featuring pictures of the police. ${ }^{197}$ Ray Jackson, an Aboriginal community liaison officer, claimed that 'the police actually rammed the young kid'. TJ's mother, Gail Hickey, said 'these dogs [the police] ... kill[ed] my son'. ${ }^{198}$ TJ's friends and family maintained that he was terrified of the police as a result of being beaten by the police a few weeks earlier. ${ }^{199}$

The Redfern riot lasted approximately six hours. ${ }^{200}$ The Police Minister stated that the police were never 'overwhelmed' by the rioters, ${ }^{201}$ although eight required hospital treatment. ${ }^{202}$ The pre-emptive mobilisation of riot police to Redfern on the day of TJ's death has been regarded as provoking the riot. ${ }^{203}$ Birch claims that witnesses to the riot said 'the police had not only incited the initial confrontation but had themselves acted violently'. ${ }^{204}$ The mainstream media focused on the blameworthiness of the Indigenous 'rioters' and neglected the grievances of the rioters. Cohen has pointed out that moral panics place issues that have long been in existence suddenly in the 'limelight' in order to convey a sense of impulsive irrationality. ${ }^{205}$ The moral panic pervaded the Daily Telegraph's reporting, which stressed the unjustified violence by an 'uncontrollable mob' ${ }^{206}$ and vehemently defended the police against suggestions that they were to blame for TJ's death. ${ }^{207}$

\footnotetext{
194 Shaw (2000), p 300.

195 Ormesher (1995), p 21.

196 Indicating this ongoing belief among members of the Indigenous community at Redfern, the Indigenous Social Justice Association organised a rally at the place TJ was impaled by the police for 14 February 2011 to commemorate seven years since his death and protest against black deaths in custody: Jackson (2011).

$197 \quad$ Kennedy et al (2004), p 1.

198 Quoted in Anon (2004).

199 Moon and Munckton (2004).

200 Strike Force Coburn (2004), pp 52-54.

201 Totaro et al (2004), p 1.

202 Corder (2004), p 31.

203 Gargett (2005), p 10.

204 Birch (2004), p 18.

205 Cohen (2002), p 1.

206 Penberthy and Kamper (2004), p 1.

207 Miranda (2004), p 2. This was also the view put in The Australian, which claimed that suspicion of a police chase of TJ 'was based more on rumour than reason': Chulov et al (2004), p 1; Anon (2004a), p 12.
} 
The media represented the police's role in the riot purely in terms of victimisation from 'hordes of Aborigines' ${ }^{208}$ Police were championed as sacrificing 'their well-being to return order to the streets' ${ }^{209}$ In defence of the police, the Daily Telegraph made a call for the '[Indigenous] participants of this outrageous incident ... [to] be identified and prosecuted'. ${ }^{210}$ These sentiments in the media were echoed in the report of Strike Force Coburn, which the police instigated to investigate the 'civil disobedience at Redfern'. ${ }^{211}$ It emphasised the out-of-control and drunken mob. Funnell claims that the report revealed a 'complete neglect of the underlying causes of the riot'. ${ }^{212}$ The only 'cause' countenanced by the mainstream media was the sense of helplessness among the Redfern Indigenous community due to 'depression, drug and alcohol addiction, and a life of petty criminality'. ${ }^{213}$ Mike Carlton wrote in the Sydney Morning Herald that the community was 'lashed by scourges of alcohol, heroin, prostitution, crime, illiteracy, innumeracy and ignorance'. ${ }^{214}$ This imagery of irrational despair prevented understandings of the 'riot' as a reasoned response to police involvement in TJ's death. It also enforced a narrative that The Block had spiralled into 'uncontrollable lawlessness and incivility' to justify plans for its closure. ${ }^{215}$ Shaw argues that "Whiteness" was threatened during the riot as [its] control was lost'. ${ }^{216}$ Accordingly, new fantasies emerged about the need for police to be defended in sentencing.

\section{Trials and Sentencing of the Redfern Rioters}

Fourteen people were charged following the Redfern riot, with the offences of riot, affray, violent disorder, throwing a missile and assaulting police. The two cases that were reported in the media were those of Marilyn Cargill, who was TJ's aunt, and Raymond Carr, TJ's cousin. The audio recording of the review of Cargill's sentence was accessed from the New South Wales District Court; all other sentencing remarks were quoted in mainstream newspapers. Initially, Redfern Local Court refused Cargill bail due to the seriousness of the offence because of the threats made against police, and despite her plea for permission to attend TJ's funeral and the court's recognition of the loss of her nephew. ${ }^{217}$ Notwithstanding 'vague and unspecific' evidence, based on police testimony linking Cargill to the riot, she was convicted and imprisoned for one year due to the seriousness of the

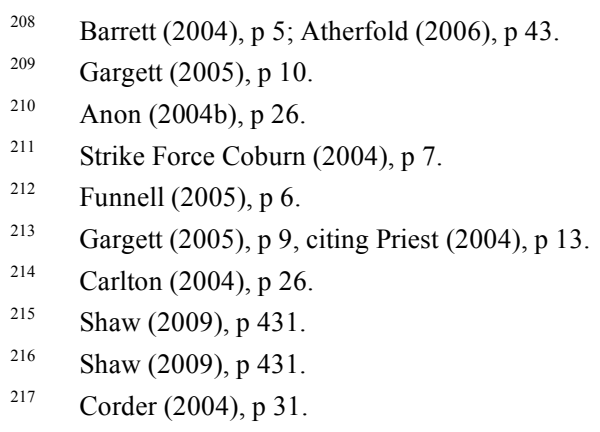


offence. ${ }^{218}$ The District Court held that her anger at the death was not relevant. ${ }^{219}$ When her sentence was reviewed after three months, following a parole and probation report recommendation, the District Court released Cargill from prison citing mental health problems and the fact that Cargill 'regarded the young person TJ Hickey as a son and was most distressed in regards to his death'. ${ }^{220}$

The deemed ringleader of the riot, ${ }^{221}$ Raymond Carr, was also charged with riot, affray, throwing bottles at police and maliciously damaging a police car. Carr told the Central Local Court in Sydney that he threw bottles at police and cars because 'he was angry at the death of Thomas Hickey'. ${ }^{222}$ Magistrate Moore refused bail, saying the defendant played 'a significant role' in the Redfern riot and the seriousness of the offence was to prevail over the reasons that explained his culpability. ${ }^{223}$ His prison sentence of twelve months reflected the objective seriousness of the offence. ${ }^{224}$ On appeal, the District Court refused to consider mitigating evidence of TJ's death during the police chase. The court focused on the harm that Carr caused, stating that the sentence 'was about as low' as he could hand down, given that he smashed a vehicle window and brandished pavers at police. ${ }^{225}$

Although the quotes from the judgments are mostly based on selective media reporting, it appears from the Cargill and Raymond cases that the courts were mindful foremost of the seriousness of the offence. While the District Court gave some leniency to the personal despair caused by TJ's death, it was not raised in relation to the grievances underpinning the riot. Rather, the riot was presented as a serious event and its portrayal lacked reference to the spatial contest and particularly the Indigenous right to such space. In this way, the court was playing the role of the 'spatial manager', who constructs the Other as 'standing between them and their imaginary nation'. ${ }^{226}$ Hage describes spatial managers as seeking to remove 'undesirable' Others from 'national [white] space'. ${ }^{227}$ Courts not only have the discursive power to manage space, but also the punitive capacity for enforcement, which was used unhesitatingly with the Redfern rioters. This power would be taken a step further in sentencing the protesters to Mulrunji's death in custody on Palm Island.

\footnotetext{
218 New South Wales District Court quoted in Levett and Kennedy (2004), p 6. 


\section{The PaIm Island Protest and the Denial of the Death in Custody in Sentencing}

In the sentencing of the Palm Island riot offenders of 2004, the Queensland Court of Criminal Appeal and District Court ruled that the death in custody of Mulrunji was not a relevant consideration. This position converged with a moral panic about the riot and its disorderly Indigenous participants who were without a legitimate cause. The judicial remarks and media reports reflected a broader social misgiving about the riot and the dysfunctional status of the Indigenous community on Palm Island. However, the media and sentencing process did not identify this tumultuous history, but focused on the irrationality and uncivilised nature of the rioters and the serious harm caused by the riot. In reality, the riot merely brought into the "limelight" 228 the historical problems on Palm Island, including in relation to punitive policing, which are a legacy of the Island's formation as a penal colony for Indigenous people in the $1920 \mathrm{~s}^{229}$

\section{Background to the Palm Island Riot and Media Indignation}

Mulrunji, 36, a widely respected Palm Island community member who had virtually no criminal record, died 40 minutes after being arrested for offensive language. ${ }^{230}$ On 19 November 2004, Sergeant Chris Hurley arrested and detained Mulrunji in Palm Island police station, where he died as a result of sustaining a black eye, four broken ribs, a ruptured liver and portal vein. The following day, Sergeant Hurley's 'mates' who had been connected with the police command investigated the death and Hurley's role. ${ }^{231}$ The 'relationships between the investigating police officers and the police officer under investigation ${ }^{232}$ sent a message to the Indigenous community that injustice would prevail. Anger within the community intensified when Indigenous people were told that Mulrunji's death occurred accidentally when he slipped on a step. ${ }^{233}$

Public meetings were held in the following week to discuss the death and prejudicial investigation. This culminated in a protest on 26 November

\footnotetext{
228 Cohen (2002), p 1.

229 Hooper (2008), p11.

230 This was in direct contradistinction to RCIADIC's (1991) recommendations: to refrain from arresting Indigenous people for offensive language (Recommendation 86a); that arrest should be the sanction of 'last resort' (Recommendation 87).

231 The Queen v Lex Patrick Wotton [2008] Townsville District Court (Unreported, 7 November, TOWN3/2008) at 2-3. The RCIADIC (1991) recommended that an investigation into a death in custody should be conducted independently from the responsible officers (Recommendations 27, 33, RCIADIC 1991). The internal investigation on Palm Island went against Recommendation 33 in the RCIADIC (1991) report, that investigating officers into a death in custody not be connected with the police command in which the death occurred.
}

$232 R v$ Wotton [2007] QDC 181 at [4].

233 The Queen v Lex Patrick Wotton [2008] Townsville District Court (Unreported, 7 November, TOWN3/2008) at 3. 
2004 in which approximately 300 people (one-eighth of the Palm Island population) assembled at the police station demanding that the police leave. The Queensland government sent 80 Tactical Response Group commandos to the island. ${ }^{234}$ The gathering threw stones and mangoes at the police building and yelled abuse at the police. The police officers were armed, pointed rifles on the crowd and were prepared to fire. ${ }^{235}$ The officers ultimately retreated to the hospital. Over the next three hours, the barracks, police station and courthouse, "which were all part of a fairly modest complex of prefabricated buildings', burnt down. ${ }^{236}$ Some officers sustained minor injuries but there were no serious injuries. Nonetheless, the Queensland Police Union, Queensland Police Commissioner and Queensland government ran a concerted campaign to highlight their sacrificial police role in the riot. This went hand in hand with the campaign to absolve Hurley of any wrongdoing associated with Mulrunji's death and to undermine the prosecution against him. ${ }^{237}$ Newspapers reported 'Police Lost Everything in Island Riots, Says Union' ${ }^{238}$ and '[Premier] Beattie Defends Police Tactics in Island Riot' ${ }^{239}$

The protest on Palm Island flooded the national media. In the mainstream media, it was portrayed as an impulsive event that was incited by a 'mob' of rioters. No reference was made to the compromised investigation into the death in custody and there was scant reference to the death in custody that precipitated the riot. ${ }^{240}$ Headlines such as 'Palm Island Erupts' ${ }^{241}$ and 'Palm Island Explodes: Anarchy on Palm Island on Knife's Edge Overnight ${ }^{242}$ cast the rioters as uncontrollable and irrational, without cause or reason. The media constructed the riot as spontaneous and excessive, rather than as arising from legitimate grievances in relation to the police. ${ }^{243}$ The pathos of the community and its deplorable living conditions were also highlighted. ${ }^{244}$ As with the Redfern riot, the police were depicted as being terrorised by the Palm Island mob. ${ }^{245}$ Newspaper headlines that

\footnotetext{
$234 \quad$ Hunter (2005), p 16.

$235 \quad R v$ Wotton [2007] QDC 181 at [6]-[7].

236 Carrick (2008). in June 2007.

238 Anon (2004d).

239 Pavey (2004).

240 Cunneen (2007); Little (2010).

241 Mancuso and Connolly (2004).

242 Lineham and Seeney (2004), p 1.

243 Anthony (2009), p 468.

244 Cunneen (2007).

245 Ketchell et al (2004b), p 30
}

237 Queensland Police Union (2005), p 26; Eastley (2004); Willoughby (2007), p 4. It was only after an independent review of the coronial evidence and a prosecution outside the office of the Director of Public Prosecutions that the responsible officer, Senior Sergeant Hurley, was prosecuted for the death of Mulrunji. Hurley was acquitted of manslaughter 
reflected this included 'How Rioters Set Trap for Police - Unarmed Officers Feared They Would Die as 300 Rampaged Trap for Police' ${ }^{246}$ and 'Police Tell of Terror' ${ }^{247}$ While this approach resonated with the judicial reasoning in sentencing the rioters, it was positioned in terms of the principles of the seriousness of the offence for the police victims.

\section{Nullification of the Death in Custody in Sentencing Palm Island Rioters}

The Palm Island riot resulted in a number of participants being charged with offences, including assaulting police, riotous assembly and rioting causing destruction. Lex Wotton was the most widely publicised protester, and would ultimately receive the harshest penalty (discussed below), but it was not his sentence that provided the precedent. The main appeal to the Queensland Court of Criminal Appeal was brought by the Attorney-General against the sentences of Jason Poynter, Alissa Norman and Russell Parker on the grounds that the sentence of the Townsville District Court failed 'to reflect the seriousness of the offence'. ${ }^{248}$ At first instance, the District Court had accounted for the death in custody as a relevant sentencing factor. For instance, in relation to Norman, the court noted that she attended the meeting that led to the 'riot' 'out of a genuine interest in how the death had occurred'. It noted that 'she shared the crowd's frustration ... that their concerns really had not been dealt with, that they really had not been fully informed' of the issues surrounding the death in custody. ${ }^{249}$

The Queensland Court of Criminal Appeal upheld the AttorneyGeneral's appeal to the sentences and provided a clear statement that that death in custody was not a relevant sentencing consideration, given the seriousness of the riot offence and police victimisation. The court denounced the rioters for targeting 'members of the police service, the very agency charged to maintain the security of persons and their property', ${ }^{250}$ while failing to recognise the gathering's grievance that such protection had not been afforded to Mulrunji. This victimisation rendered the riot 'distinctly grave' ${ }^{251}$ At the same time, the court accepted that there were no serious injuries (the worst being a fractured rib), and the greatest threat was to the rioters themselves. ${ }^{252}$ The court quoted a victim's impact statement by a police officer that recalled that he had 'made a cold, logical decision to fire into a large crowd if necessary' ${ }^{253}$ However, it was the threat that the riot

\footnotetext{
$246 \quad$ Ketchell et al (2004a), p 4.

Ketchell (2004a), p 6; see also Ketchell (2004b), p 5; Anon (2004c), p 4.

$R v$ Poynter, Norman \& Parker; ex parte A-G (Qld) [2006] QCA 517 at [15], [21], [28].

Quoted in $R v$ Poynter, Norman \& Parker; ex parte A-G (Qld) [2006] QCA 517 at [20].

$R v$ Poynter, Norman \& Parker; ex parte A-G (Qld) [2006] QCA 517 at [30].

$R v$ Poynter, Norman \& Parker; ex parte A-G (Qld) [2006] QCA 517 at [35].

$R v$ Poynter, Norman \& Parker; ex parte A-G (Qld) [2006] QCA 517 at [29].

$R v$ Poynter, Norman \& Parker; ex parte A-G (Qld) [2006] QCA 517 at [29].
} 
presented to the police that was the significant consideration in sentencing. ${ }^{254}$ The court referred to the 60 pages of victim impact statements provided by police officers that described 'the terror they experienced' and how they 'feared for their lives, with some telephoning family members to say goodbye'. ${ }^{255}$

The Court of Criminal Appeal noted repeatedly the need to deter riot offenders and the Indigenous community generally from committing such offences. ${ }^{256}$ McMurdo $\mathrm{P}$ described riots as 'terrifying and destructive' and said the Palm Island riot was a 'notorious event in Queensland's history' that could not be allowed to occur again. ${ }^{257}$ De Jersey CJ quoted $R v$ $M c C_{\text {Ormack }}{ }^{258}$ on the necessity of a custodial sentence for riot offenders to promote deterrence: '[C]ourts have commonly regarded an attack on the police in the execution of their duty as calling for custodial sentence with a deterrent component. ${ }^{259}$ The court's approach to deterrence assumed that the rioters were acting with free and individual agency, ${ }^{260}$ and overlooked the context that impelled the protest. The court viewed the offence as based on a simple calculation that, with the threat of harsh punishment, it would not be repeated.

Ultimately, the court decided that the death in custody was not a relevant sentencing consideration. The court stated that the fact that 'one police officer is perceived - whether or not with justification - to have done a terribly bad thing, does not justify the wholesale, violent, condemnation of the contingent of which he forms part'. ${ }^{261}$ McMurdo P remarked that 'Mulrunji's death ... and its subsequent investigation ... does not excuse the rioters' resort to lawlessness in pursuit of their cause' ${ }^{262} \mathrm{He}$ went on to note that the 'rioters could have expressed their concerns through lawful channels' ${ }^{263}$ After all, they had been told that 'an inquiry was underway and the matter was to be referred to the Crime and Misconduct Commission' ${ }^{264}$ De Jersey CJ stated unequivocally that the death in custody lacked significance:

$254 \quad R v$ Poynter, Norman \& Parker; ex parte A-G (Qld) [2006] QCA 517 at [5].

$255 \quad R v$ Poynter, Norman \& Parker; ex parte A-G (Qld) [2006] QCA 517 at [5] (see also at [29]). See also $R v$ Poynter, Norman \& Parker; ex parte A-G (Qld) [2006] QCA 517 at [29].

$256 \quad R$ v Poynter, Norman \& Parker; ex parte A-G (Qld) [2006] QCA 517 at [30], [38].

${ }^{257} R$ v Poynter, Norman \& Parker; ex parte A-G (Qld) [2006] QCA 517 at [60], [71].

$258 \quad R v$ McCormack \& Ors [1981] VR 104.

$259 \quad R v$ Poynter, Norman \& Parker; ex parte $A-G($ Qld) [2006] QCA 517 at [33], quoted in $R v$ McCormack \& Ors [1981] VR 104 at 109.

260 See criticisms of this assumption by Lacey (1988), pp 59-61; Duff (1998), p 149; Ashworth (2005), p 86.

$261 \quad R v$ Poynter, Norman \& Parker; ex parte $A-G($ Qld) [2006] QCA 517 at [35] (emphasis added).

$262 \quad R v$ Poynter, Norman \& Parker; ex parte A-G (Qld) [2006] QCA 517 at [71].

$263 R v$ Poynter, Norman \& Parker; ex parte A-G (Qld) [2006] QCA 517 at [71].

$264 \quad R v$ Poynter, Norman \& Parker; ex parte A-G (Qld) [2006] QCA 517 at [71]. 
Mr Devereaux SC, who appeared for the respondent Parker, submitted that 'the riot in this case was not directed at police as a result of their carrying out their lawful duty, but was a response to perceived unlawful fatal violence by a police officer on a community member'. That may be, but for sentencing purposes, the point lacks significance. ${ }^{265}$

The court stressed that 'mob conduct at the police station was a reaction which could not be tolerated in a civilized community'. ${ }^{266}$ It pointed to 'recent and not so recent world history [that] illustrates the immense danger wrought by riots' and their potential to lead to 'anarchy'. ${ }^{267}$ Therefore, the Indigenous community was imagined not only as lacking a cause, but also as lacking civilisation. The court's imagery of an uncivilised anarchical mob terrorising defenceless police dovetails the media's language and reflects the social perception that the Indigenous community lacked reason or restraint. This message was carried through in the sentencing of Lex Wotten.

\section{Application of Decontextualised Sentencing Approach to Lex Wotton}

Lex Wotton was regarded as the ringleader of the Palm Island riot, although the courts did not establish whether he was an instigator or conciliator between the rioters and police ${ }^{268} \mathrm{He}$ was charged under section 65 of the Criminal Code (Qld) for partaking in a riot in which a building was destroyed. Of the Palm Islanders involved in the protest, Wotton was charged with the most severe offence. The 37-year-old was a long-term Indigenous activist and community leader who was involved in rehabilitation and healing programs. ${ }^{269}$ These facts were taken into account in relation to Wotton's character, but not in relation to understanding Wotton's culpability in the riot itself. ${ }^{270}$ Nonetheless, the police described him as a serious offender and sought to make an example of him by pressing the most severe charges. Indeed, police identified Wotton 'as the person that they would shoot first' if the riot turned sour. ${ }^{271}$ Ultimately, Wotton would receive the longest sentence of all the rioters.

265

$R v$ Poynter, Norman \& Parker; ex parte A-G (Qld) [2006] QCA 517 at [31] (emphasis added).

266

267

268

$R v$ Poynter, Norman \& Parker; ex parte A-G (Qld) [2006] QCA 517 at [36].

$R v$ Poynter, Norman \& Parker; ex parte A-G (Qld) [2006] QCA 517 at [37], [39].

The Townsville District Court found that Wotton attempted to assist the police to get off the island in order to prevent their harm: The Queen v Lex Patrick Wotton [2008] Townsville District Court (Unreported, 7 November, TOWN3/2008) at 8-9.

The Queen v Lex Patrick Wotton [2008] Townsville District Court (Unreported, 7 November, TOWN3/2008) at 13.

These submissions were accepted per Penalties and Sentences Act 1992 (Qld), s9(2)(p), which allows any 'any submissions made by a representative of the community justice group in the [Indigenous] offender's community'.

The Queen v Lex Patrick Wotton [2008] Townsville District Court (Unreported, 7 November, TOWN3/2008) at 11. 
In December 2008, four years after the riot, the Townsville District Court sentenced Wotton to six years' imprisonment, eligible for parole after two years. In the meantime, Wotton had faced a trial by media, adverse police publicity and criticisms by courts hearing preliminary matters that he was 'morally wrong'. ${ }^{272}$ The District Court followed the Queensland Court of Criminal Appeal in $R v$ Poynter, Norman \& Parker (2006) by disavowing the circumstances of the death in custody and the mishandled investigation, and focusing instead on deterrence and the seriousness of the offence, especially as police officers were victims. The District Court noted:

\begin{abstract}
the Court of Appeal has indicated that the background to this matter [ie the death in custody] is not particularly relevant for the purpose of the sentence. The reason for that, in my view, is the serious nature of the offence itself, rioting with destruction. ${ }^{273}$
\end{abstract}

The District Court recognised that the 'history and disadvantages of Palm Island' - which include widespread poverty, unemployment and illness - '[are] not something for which successive administrations of this State and the Commonwealth could in any way be proud' ${ }^{274}$ This acknowledgement did not result in sentencing mitigation, but merely recognition of the helplessness of the population that was beyond repair. Shanahan J concluded that 'it is a community that faces a number of serious problems and has for a number of years' ${ }^{275}$ The riot was viewed as part of these problems ${ }^{276}$ rather than as being caused by the problems and an expression of the ongoing spatial contest on the island. The court's attribution of the riot to the Indigenous community rather than problems arising from white control contrasts with the High Court's reasoning in Neal $v$ The Queen, in which Indigenous dissent was a valid response to white authority. ${ }^{277}$ The District Court and the Queensland Court of Appeal primarily considered the serious danger that the riot presented to 'ideal' ${ }^{278}$ police victims and the uncivilised nature of the Palm Island community. ${ }^{279}$ These characterisations of Indigenous people as uncivilised are matched with, in the words of Hage, attempts at 'domestication' to bring nature in line with humans. ${ }^{280}$ This

\footnotetext{
272 See $R v$ Wotton [2007] QDC 181 at [8].

273 The Queen v Lex Patrick Wotton [2008] Townsville District Court (Unreported, 7 November, TOWN3/2008) at 4 (emphasis added).

274 The Queen v Lex Patrick Wotton [2008] Townsville District Court (Unreported, 7 November, TOWN3/2008) at 2.

275 The Queen v Lex Patrick Wotton [2008] Townsville District Court (Unreported, 7 November, TOWN3/2008) at 2 .

276 The Queen v Lex Patrick Wotton [2008] Townsville District Court (Unreported, 7 November, TOWN3/2008) at 11-12.

$277 \quad$ Neal v The Queen (1982) 149 CLR 305 at 318.

$278 \quad$ Christie (1986), p 18.

$279 R$ v Poynter, Norman \& Parker; ex parte A-G (Qld) [2006] QCA 517 at [36], [39].

280 Hage (1998), p 170.
} 
judicial mindset only leaves room for punitive sentencing that seeks to teach the offender a lesson through a lengthy prison sentence.

\section{Concluding Remarks}

Within sentencing legislation and common law principles, there is broad scope to consider the circumstances of the offence to assess the culpability of the offender. Indeed, individualised justice is regarded as a lynchpin of the Australian sentencing regime. This approach can result in courts creating fantasises about white tolerance for Indigenous grievances and providing mitigation. It depends on the myth of the universality of white space that allows some difference at the margins. However, such fantasies are Janusfaced with, as Hage and Rutherford alert us, the side of 'good' nationalist sentiments easily turning to the side of 'evil nationalism' when morality converges with desires for white integration. ${ }^{281}$ Recent sentencing remarks dealing with Indigenous rioters have privileged considerations of the seriousness of the offence with reference to the harm to police victims over a consideration of the violent circumstances provoking the riot. These courts have referred to the rioters as out of control and uncivilised. They have retreated from attributing the rioters with a legitimate political grievance as the High Court did in Neal and the New South Wales Court of Criminal Appeal did in the Brewarrina cases. The Indigenous community now is cast as presenting a serious danger to society due to its impulsive violence directed at the police.

In reimagining the Indigenous community in order to lengthen prison sentences, courts set up a number of culturally contingent binaries. The danger of the Indigenous people's offence is contrasted with the innocence of police victims. The disorder of the Indigenous community is contrasted with the law and order provided by the police. The uncivilised anarchy of the Indigenous community is contrasted with the civilisation of the police. Pervading these binaries is the enforcement of neutral sentencing principles of serious harm and victimisation that ostensibly remove considerations of Indigenous difference. However, when applied, they give rise to longer sentences for Indigenous offenders by ignoring factors that may reduce their culpability including the circumstances of the death in custody in the context of over-policing Indigenous spaces. Cowlishaw comments in her analysis of the 1997 Bourke riot case that: 'In the highly ritualized legal arena there was no moment when the rioters' rage could be attended to, and no possibility of any respect being paid to its genesis or its justification. ${ }^{282}$ This is because courts have come to focus on the violence and thereby reinforce the threat of the Other. Judicial responses and media moral panics in relation to Indigenous riots bring into the limelight the underlying nationalist impulse to assert a white order over the Other. ${ }^{283}$ For sentencing courts to take

\footnotetext{
$281 \quad$ Hage (1998), p 79; Rutherford (2000), p 27.

282 Cowlishaw (2004), p 237.

$283 \quad$ Hage (1998), p 17.
} 
meaningful account of Indigenous factors, they need to be contextualised within historical and political contests over space. To do otherwise is to pathologise the Indigenous riot and deny its purpose.

\section{References}

TW Adorno, TW, E Frenkel-Brunswik, DJ Levinson and RN Sanford (1950) The Authoritarian Personality, Vols 1 and 2, Harper.

Kay J Anderson (1993) 'Constructing Geographies: "Race”, Place and the Making of Sydney's Aboriginal Redfern', in Peter Jackson and Jan Penrose (eds), Constructions of Race, Place and Nation, UCL Press.

Kay J Anderson (1999) 'Reflections on Redfern', in Elaine Stratford (ed), Australian Cultural Geography, Oxford University Press.

Ien Ang (1999) 'Racial/Spatial Anxiety: "Asia" in the Psycho-Geography of Australia Whiteness', in Ghassan Hage and Rowanne Couch (eds), The Future of Australian Multiculturalism: Reflections on the Twentieth Anniversary of Jean Martin's The Migrant Presence, Research Institute for Humanities and Social Sciences, University of Sydney.

Anon (1987) 'Police Hurt in Clash With Aborigines', AAP [online Factiva database], 16 August.

Anon (1987a) 'A Riot at Brewarrina', Sydney Morning Herald, 18 August, p 16.

Anon (2004a) 'No Excuses Can Exonerate Redfern Riot', The Australian, 18 February, p 12.

Anon (2004b) 'Upholding the Law', Daily Telegraph, 20 February, p 26.

Anon (2004c) 'Police Flee After Island Rampage Over Jail Death', Hobart Mercury, 27 November, $\mathrm{p} 4$.

Anon (2004d) 'Police Lost Everything in Island Riots, Says Union', AAP [online Factiva database], 29 November.

Anon (2004e) 'Brogden's Riot Response: Bulldoze The Block', Sydney Morning Herald, 16 February, www.smh.com.au/articles/2004/02/16/1076779880553.html.

Anon (2004f) 'Police “Deserve All They Get”: Dead Teen's Mum', AAP [online Factiva database], 16 February.

Thalia Anthony (2010), Sentencing Indigenous offenders, Indigenous Justice Clearinghouse, Brief 7, March.

Thalia Anthony (2009), 'Manifestations of Moral Panics in the Sentencing of Palm Islander Lex Wotton' 20(3) Current Issues in Criminal Justice 466.

Andrew Ashworth (2002) 'Sentencing', in Mike Maguire et al (eds), Oxford Handbook of Criminology, 3rd ed, Oxford University Press.

Andrew Ashworth (2005) Sentencing and Criminal Justice, 4th ed, Cambridge University Press. Joanna Atherfold (2006) 'Redfern: The "Riot" and the Reporting' 17 Australian Studies in Journalism 41.

Steve Barrett (2004) 'Riot Controllers "Put Lives at Risk"', The Australian, 17 March, p 5.

William J Bennett, John J Dilulio Jnr and John P Walters (1996) Body Count: Moral Poverty and How to Win America's War Against Crime and Drugs, Simon \& Schuster.

Tony Birch (2004) “"Who Gives a Fuck About White Society Anymore?”: A Response to the Redfern Riot' 175 Overland 18.

Mike Carlton (2004) 'The Recipe for a Riot', Sydney Morning Herald, 21-22 February, p 26.

Damien Carrick (2008) 'The Sentencing of Lex Wotton', The Law Report, ABC Radio, 11 November. 
Jenny Carter (1987) 'What if They Held a Riot and Nobody Came?', Sydney Morning Herald, 18 August, $\mathrm{p} 18$.

Paul Carter (2007) 'Public Space: Its Mythopoetic Foundations and the Limits of the Law' 16(2) Griffith Law Review 430.

Nils Christie (1986) 'The Ideal Victim', in Ezzat A Fattah (ed), From Crime Policy to Victim Policy: Reorienting the Justice System, Macmillan.

Martin Chulov et al (2004) 'Rumour: The Spark that Fired Racial Tinderbox' The Australian, 17 February, $\mathrm{p} 1$.

Stanley Cohen (2002) Folk Devils and Moral Panics, 3rd ed, Routledge.

Colman, Elizabeth (2004) 'Magistrate Refuses Bail for Alleged Riot Ringleader' The Australian, 25 February, p 7.

Mike Corder (2004) 'Dead Boy's Aunt in the Dock over Sydney Riot', The Independent (London), 21 February, p 31.

Gillian Cowlishaw (2004) Blackfellows Whitefellows and the Hidden Injuries of Race, Blackwell.

Kimberlé Crenshaw (1991) 'Mapping the Margins: Intersectionality, Identity Politics, and Violence Against Women of Colour' 43(6) Stanford Law Review 1255.

Chris Cunneen (1990) Aboriginal/Police Relations in Redfern with Special Reference to the Police Raid of 8 February 1990, Human Rights and Equal Opportunity Commission.

Chris Cunneen (2001) Conflict, Politics and Crime: Aboriginal Communities and the Police, Allen \& Unwin.

Chris Cunneen (2007) 'Riot, Resistance and Moral Panic: Demonising the Colonial Other', in Scott Poynting and George Morgan (eds), Outrageous! Moral Panics in Australia, ACYS Publishing.

Chris Cunneen and Tom Robb (1987) Criminal Justice in North-West New South Wales, New South Wales Bureau of Crime Statistics and Research.

Jennie Curtin (1992) 'Riot Verdicts Set Aside on Appeal', Sydney Morning Herald, 7 April, p 7. Ann Curthoys (1999) 'An Uneasy Conversation: Multicultural and Indigenous Discourses', in Ghassan Hage and Rowanne Couch (eds), The Future of Australian Multiculturalism: Reflections on the Twentieth Anniversary of Jean Martin's The Migrant Presence, Research Institute for Humanities and Social Sciences, University of Sydney.

Tony Duboudin (1987) 'Five Hurt in Violent Clash with Police: Aborigines Protest Over Deaths in Custody', The Times 17 August.

RA Duff (1998) 'Dangerousness and Citizenship', in Andrew Ashworth and Martin Wasik (eds), Fundamentals of Sentencing Theory: Essays in Honour of Andrew von Hirsch, Clarendon Press.

Tony Eastley (2004) 'Queensland Police Commissioner Defends Palm Island Response', AM, ABC Radio, 30 November.

Susan Easton and Christine Piper (2005) Sentencing and Punishment: The Quest for Justice, Oxford University Press.

Richard Edney and Mirko Bagaric (2007) Australian Sentencing: Principles and Practice, Cambridge University Press.

Janet Fife-Yeomans (1988) 'Racial Anger Case Begins', Sydney Morning Herald, 26 July, p 8.

Robert M Fogelson (1968) 'Violence as Protest', in Robert H Connery (ed), Urban Riots: Violence and Social Change, Proceedings of the Academy of Political Science, Vol XXIX No 1, Academy of Political Science, Columbia University. 
Kari Forbes-Boyte (2009) 'Whiteout? Gentrification and Colonialism in Inner-City Sydney' 13(1) City 153.

Ruth Frankenberg (1993) White Women, Race Matters: The Social Construction of Whiteness, University of Minnesota Press.

Erich Fromm (1963) The Dogma of Christ and other Essays on Religion, Psychology and Culture, Routledge \& Kegan Paul.

Neal Funnell (2005) 'Non-Lethal Intelligence: Strike Force Coburn and the Police Response to the Redfern Riot' 6(10) Indigenous Law Bulletin 4.

Andy Gargett (2005) 'A Critical Media Analysis of the Redfern Riot' 6(10) Indigenous Law Bulletin 8.

David Garland (2001) The Culture of Control: Crime and Social Order in Contemporary Society, Oxford University Press.

AM Gleeson (1995) 'Individualised Justice - The Holy Grail' 69 Australian Law Journal 421.

Tom Gray, Sally Burgess and Martin Hinton (2008) 'Indigenous Australians in Sentencing', in Elliott Johnston, Martin Hinton and Daryle Rigney (eds), Indigenous Australians and the Law, 2nd ed, Routledge-Cavendish.

Ghassan Hage (1998) White Nation: Fantasies of White Supremacy in a Multicultural Society, Pluto Press.

Ghassan Hage (2003) Against Paranoid Nationalism: Searching for Hope in a Shrinking Society, Pluto Press.

Annette M Hennessy (2006) 'Indigenous Sentencing Practices in Australia', paper presented at the International Society for Reform of the Criminal Law Conference, Justice for All Victims, Defendants, Prisoners and Community, Brisbane, July, www.austlii.edu.au/au/journals/QldJSchol/2006/102.html.

Tony Hewett (1987) 'Race Riots: More Towns are at Risk', Sydney Morning Herald, 18 August, $p 1$.

Tony Hewett (1987a) 'Blood on the Street The Night a Town Exploded', Sydney Morning Herald, 17 August, $\mathrm{p} 1$.

Russell Hogg (2008) 'Resisting a "Law and Order" Society', in Thalia Anthony and Chris Cunneen (eds), The Critical Criminology Companion, Hawkins Press.

Chloe Hooper (2008), The Tall Man: Death and Life on Palm Island, Hamish Hamilton.

Deborah Hope (1991) 'Call to Discipline Police Over Aborigine's Death', Sydney Morning Herald, 10 April, p 2.

Barbara Hudson (1999), 'Punishment, Poverty and Responsibility: The Case for a Hardship Defence' 8 Social Legal Studies 583.

Catherine Hunter (2005) 'Palm Island: The Truth Behind the Media Portrayal - an Interview with Erykah Kyle, Chairperson of the Palm Island Aboriginal Council' 6(12) Indigenous Law Bulletin 16.

Ray Jackson, '7th Anniversary of the Death of TJ Hickey, 20 January 2011' $\mathrm{http}: / /$ workersbushtelegraph.com.au/2011/01/20/7th-anniversary-of-the-death-of-tj-hickey.

Elliott Johnston (1991) National Report: Royal Commission into Aboriginal Deaths in Custody, Vol 1, Australian Government Publishing Service.

Les Kennedy et al (2004), 'Chased or Not, TJ had Reasons to Run' Sydney Morning Herald, 17 February, $\mathrm{p} 1$.

Melissa Ketchell (2004a) “"They Were Saying They Would Kill Us”: Police Tell of Terror', Sunday Mail, 28 November, p 6. 
Melissa Ketchell (2004b) 'Where the Thin Blue Line Walks in Fear', Sunday Mail, 28 November, p 5.

Melissa Ketchell et al (2004a) 'How rioters set trap for police - Unarmed officers feared they would die as 300 rampaged trap for police', The Sunday Mail, 28 November, p 4.

Melissa Ketchell et al (2004b) 'Police Riot Terror', Herald Sun, 28 November, p 30.

Nicola Lacey (1988) State Punishment: Political Principles and Community Values, Routledge.

Leonie Lamont (2005) 'Rioter Loses Jail-Term Appeal', Sydney Morning Herald, 15 February, p 5.

Connie Levett and Les Kennedy (2004) 'Teen's Aunt to Miss Funeral as Bail Denied', Sydney Morning Herald, 21 February, p 6.

Daniel Lewis (1991a) 'Funeral riot: Jury Told to Ignore Cell Deaths Report', Sydney Morning Herald, 13 April, p 6.

Daniel Lewis (1991b) 'Blacks' Behaviour has Deteriorated: Brewarrina Riot Judge', Sydney Morning Herald, 9 May, p 3.

Daniel Lewis (1991c) 'Two Found Guilty Over Brewarrina Funeral Riot', Sydney Morning Herald, 17 April, p 3.

Sheree Lineham and Hayley Seeney (2004) 'Palm Island Explodes: Anarchy on Palm Island on Knife's Edge Overnight', Townsville Bulletin, 27 November, $\mathrm{p} 1$.

Janine Little (2010) 'Journalism, Creative Non-fiction and Australia's Black History: The Tall Man and Cross-cultural Source Relationships' 32(2) Australian Journalism Review 47.

Roberta Mancuso and Steve Connolly (2004) 'Palm Island Erupts: Buildings Burn, Police Threatened', AAP [online Factiva database], 26 November.

Candace McCoy (1997) 'Review Essay: Sentencing (and) the Underclass' 31(3) Law \& Society Review 589.

Charles Miranda (2004) 'Setting the Stage for a Violent Showdown' Daily Telegraph, 17 February, p 2.

Kylie Moon and Stuart Munckton (2004) 'Redfern "Riot": Black Youth Fight Back', Green Left Weekly, www.greenleft.org.au/node/30460, 25 February.

Barry Morris (2001) 'Policing Racial Fantasy in the Far West of New South Wales' 71(3) Oceania 242.

Cameron McAuliffe (2009) 'Book Review: Cities of Whiteness' 99(3) Annals of the Association of American Geographers 627.

Pat O'Malley (2004) 'The Uncertain Promise of Risk' 37 Australian and New Zealand Journal of Criminology 323.

Patricia Ormesher (1995) 'The Background of Redfern: Assimilation, Post/assimilation and Australian Racism' 59 Nelen Yubu 16.

Ainsley Pavey (2004) 'Beattie Defends Police Tactics in Island Riot', AAP [online Factiva database], 29 November.

David Penberthy and Angela Kamper (2004) 'Flashpoint - Redfern ... Sydney ... 1am ... February 16 ... 2004 - The Redfern Riots' Daily Telegraph, 17 February, p 1.

Roderic Pitty (1994) 'Brewarrina Riot: The Hidden History' 3(70) Aboriginal Law Bulletin 9.

John Pratt (2008) 'Penal Populism and the Contemporary Role of Punishment', in Thalia Anthony and Chris Cunneen (eds), The Critical Criminology Companion, Hawkins Press.

Tim Priest (2004) 'Stop the Social Engineering and Empower Sydney Police', The Australian, 18 February, p 13.

Queensland Police Union (2005) Police Journal, July. 
Redfern Residents for Reconciliation (2011) 'Redfern Oral History Timeline' www.redfernoralhistory.org/Timeline/Timeline/tabid/239/Default.aspx.

Royal Commission into Aboriginal Deaths in Custody (RCIADIC) (1991) National Report, Australian Government Publishing Service.

Jennifer Rutherford (2000) The Gauche Intruder: Freud, Lacan and the White Australian Fantasy, Melbourne University Press.

Phil Scraton (2007) Power, Conflict and Criminalisation, Routledge.

Wendy Shaw (2000) 'Ways of Whiteness: Harlemising Sydney's Aboriginal Redfern' 38(3) Australian Geographical Studies 291.

Wendy Shaw (2007) Cities of Whiteness, Wiley-Blackwell.

Wendy Shaw (2009) 'Riotous Sydney: Redfern, Macquarie Fields, and (My) Cronulla' 27 Environment and Planning D: Society and Space 425.

Allan Silver (1976) 'The Demand for Order in Civil Society' in David J Bordua (ed), The Police, John Wiley.

Jonathan Simon (2007) Governing Through Crime: How the War on Crime Transformed American Democracy and Created a Culture of Fear, Oxford University Press.

Ceridwen Spark (2003) 'Documenting Redfern: Representing Home and Aboriginality on The Block' 17(1) Continuum: Journal of Media \& Cultural Studies 33.

Strike Force Coburn (2004) Final Report - Part A Analysis - Redfern Local Area Command Civil Unrest 15-16 February 2004, New South Wales Police.

Cyrus Tata (2007) 'Sentencing as Craftwork and the Binary Epistemologies of the Discretionary Decision Process' 16(3) Social and Legal Studies 425.

Cyrus Tata (2010) 'A Sense of Justice: The Role of Pre-sentence Reports in the Production (and Disruption) of Guilt and Guilty Pleas' 12 Punishment \& Society 239.

Colin Tatz (1996) 'Opinion: Black Search For Meaning' The Age, 5 January, p 11.

Robert Tickner (1982) 'Redfern: A Return to the Early 1970s?' 1(4) Aboriginal Law Bulletin 3.

Michael Tonry (1995) Malign Neglect: Race, Crime and Punishment in America, Oxford University Press.

Paola Totaro et al (2004) 'Alcohol, Heat, Grief Triggered the Riot', Sydney Morning Herald, 17 February, $\mathrm{p} 1$.

Andrew von Hirsch (2004) 'Scaling Punishments: A Reply to Julia Davis', in Cyrus Tata and Neil Hutton (eds), Sentencing and Society: International Perspectives, Ashgate.

Sonya Voumard (1992) 'Convictions Over Riot Set Aside by Judge', The Age, 7 April, p 10.

Joanne Watson (2010) Palm Island: Through a Long Lens, Aboriginal Studies Press.

Graham Williams (1988) 'Boney on Police: "I'm Just Frightened of Them Bastards"', Sydney Morning Herald, 10 February, p 7.

Graham Williams and Michael Cordell (1987a) 'Man “Too Drunk” to Hang Himself', Sydney Morning Herald, 10 August, p 8.

Graham Williams and Michael Cordell (1987b) 'No Way He Would Kill Himself, Says Aboriginal's Family', Sydney Morning Herald, 8 August, p 1.

Shannon Willoughby (2007) 'Solidarity for Hurley: Incensed Coast Cops in Protest', Gold Coast Bulletin, 31 January, $\mathrm{p} 4$.

Paul Wilson (1982) Black Deaths, White Hands, Allen \& Unwin.

Hal Wootten (1991) 'Report of the Inquiry into the Death of Lloyd James Boney', Royal Commission into Aboriginal Deaths in Custody, Australian Government Publishing Service. 


\section{Cases}

Jadurin v R (1982) 44 ALR 424

Neal $v$ The Queen (1982) 149 CLR 305

$R v$ Boney [1991] NSWCCA (Unreported, 22 July, No 60342/91)

$R v$ Cargill [2005] NSWDC (Unreported, 6 January, Audio recording of proceedings)

$R v$ Chong; ex parte A-G (Qld) [2008] QCA 22

$R v$ Churchill [2000] WASCA 230

$R v$ Fernando (1992) 76 A Crim R 58

$R v$ Fuller-Cust (2002) 6 VR 496

$R v$ McCormack \& Ors [1981] VR 104

$R v$ Minor (1992) 105 FLR 180

$R v$ Miyatatawuy (1996) 87 A Crim R 574

$R v$ Murray, $R v$ Bates [1992] NSWCCA (Unreported, 6 April, CCA 60322 of 1991, CCA 60343 of 1991)

$R v$ Poynter, Norman \& Parker; ex parte A-G (Qld) [2006] QCA 517

$R v$ Shannon (1991) 56 A Crim R 56

$R v$ Whyte (2002) 134 A Crim $R 53$

$R v$ Wotton [2007] QDC 181

Rogers and Murray $v$ The Queen (1989) 44 A Crim R 301

The Queen v Lex Patrick Wotton [2008] Townsville District Court (Unreported, 7 November, TOWN3/2008)

Veen $v$ The Queen (No 1) (1979) 143 CLR 458

Veen $v$ The Queen (No 2) (1988) 164 CLR 465

Wong v The Queen; Leung v The Queen (2001) 207 CLR 584

\section{Legislation}

Crimes (Sentencing Procedure) Act 1999 (NSW)

Criminal Code Compilation Act (WA)

Penalties and Sentencing Act 1992 (Qld)

Sentencing Act (NT) 